УДК 811.163.1'34

371.3::811.163.41

https://doi.org/10.18485/kij.2018.65.1_2.9

НИКОЛА В. РАДОСАВЉЕВИЪ *

Универзитет у Београду

Филолошки факултет
Оригинални научни рад

Примљен: 01. 05. 2018.

Прихваћен: 26. 05. 2018.

\title{
О (НЕ)АКЦЕНТОВАНОСТИ И ФОНЕТСКОЈ ПРИРОДИ АКЦЕНАТА У ГРАМАТИКАМА ЗА СРПСКИ ЈЕЗИК И ЈЕЗИЧКУ КУЛТУРУ ОД 5. ДО 8. РАЗРЕДА ОСНОВНЕ ШКОЛЕ
}

\begin{abstract}
Рад представља један део резултата истраживања градива из акцентологије у граматикама за српски језик и језичку културу од 5. до 8. разреда основне школе. Испитује се тачност и прецизност у разграничавању акцентованих и неакцентованих речи, у дефинисању инвентара клитика и у описивању фонетске природе акценатских елемената, као једног од могућих ослонаца у савладавању акценатских опозиција. Циљ рада је да се допринесе проналажењу оптималног начина за усвајање основе акценатског система стандардног српског језика од 5. до 8. разреда основне школе.
\end{abstract}

Кључне речи: настава српског језика, фонетика и фонологија српског језика, акцентологија, фонолошке опозиције, прозодијска дистинктивна обележја, клитике.

0.0. Можемо слободно рећи да се акцентологија сматра једном од најмање заступљених области у настави српског језика и у основним и у средњим школама. Разлог за то често треба тражити ван наставних програма, у неспремности наставника да се ухвате у коштац с градивом које убрајају у теже наставне јединице из сопствене несигурности и/или страха да га ђаци неће успешно савладати. Стога су, нажалост, часови посвећени наставним јединицама из акцентологије, ако већ нису замењени другим јединицама, углавном лишени практичних вежбања изговарања елемената акцентуације, те тиме и кључног исходишта - усвајања вештине акцентовања текста - и бивају сведени на учење напамет правила акцентовања и списка проклитика и енклитика.

"radosavljevicvnikola@gmail.com 
Иако би се штошта могло рећи о недостацима у структури наставних програма што се тиче ове области и допринети у развијању практичних вежбања као помоћ наставнику, најпре ваља анализирати оно што се често олако занемарује - теоријску подлогу из акцентологије која се наставнику и ђаку пружа у нашим граматикама, будући да је то главни извор основних знања из ове области и ослонац акценатских вежби.

0.1. Предмет овог рада је поступак обраде једног дела градива из акцентологије у граматикама српског језика и језичке културе од 5. до 8. разреда основне школе. Истраживање је извршено на корпусу најновијих издања граматика следећих издавача (редослед референци је према разредима, од V до VIII):

1) Klett (Ломпар 2017a, 2017б, 2017в, 2017г);

2) Нови Логос (Срдић 2017; Срдић et al. 2017а, 2017б, 2017в);

3) Едука (Журић - Ангеловски 2015, 2012а, 2012б; Штасни - Добрић 2012);

4) Креативни центар (Маринковић 2015, 2014; Кликовац 2015, Маринковић 2013);

5) Завод за уџбенике (за 5. разред: Драгићевић 2011; Николић - Николић 2011а; Вуловић 2016; за 6. разред: Николић - Николић 2011б; Вуловић - Рудњанин 2016; за 7. разред: Милановић 2009; Николић 2011в; за 8. разред: Кликовац 2011).

0.2. Задатак је да се анализира да ли су довољно прецизно, јасно и у складу са постојећом акцентолошком литературом:

1) терминолошки разграничене акцентоване и неакцентоване речи, акцентогене/ортотоничне речи и клитике, уз опис и тумачење процеса преношења акцента на проклитику;

2) дефинисани инвентари проклитика и енклитика;

3) акценти и постакценатска дужина описани и објашњени са фонетског и фонолошког становишта, и из позиције импликација тих описа и објашњења по упознавање, савладавање и усвајање фонолошких опозиција на акценатском нивоу у настави српског језика, у шта убрајамо: a) сам феномен акцента и акцентованости; б) опозицију по квантитету акцентованих слогова; в) опозицију по квалитету дугих акцентованих слогова; г) опозицију по квалитету кратких акцентованих слогова; д) опозицију по квантитету постакценатских слогова.

0.3. Циљеви рада су да се исправе недостаци, непрецизности и грешке у обради постојећег садржаја наставних јединица и да се предложе садржаји којима се настава може допунити, чиме се жели допринети стварању оптималног начина наставе акцентологије од 5. до 8. разреда основне школе.

0.4. Главни део рада подељен је на 2 целине, у којима су представљени резултати анализе из т. 0.2: 1. „О (не)акцентованости - проклитике и енклитике”; 2. „Фонетска природа акцената и постакценатских дужина”. У Закључку (3) наведена је кратка рекапитулација резултата до којих се у раду дошло. 


\section{1. О (не)акцентованости - проклитике и енклитике}

1.1. Клитике је једноставно и најбоље објаснити као речи које немају свој/ сопствени акценат (Милановић 2009: 145; Кликовац 2011a: 23; Журић - Ангеловски 2012б: 134; Штасни - Добрић 2012: 138; Ломпар 2017г: 132) и које се изговарају заједно с речју уз коју стоје и с њом чине акценатску целину (Кликовац 2011a: 23; Журић - Ангеловски 2012б: 134; Ломпар 2017г: 132; Срдић et al. 2017в: 146; Кликовац 2018: 60) или фонетску целину (Штасни - Добрић 2012: 138). Не треба их притом називати речима „које нису акцентоване” (Срдић et al. 2017в: 146), јер се тиме занемарује појава преношења акцента на проклитику: проклитика може бити акцентована „позајмивши” акценат од речи уз коју стоји, што не чини да тад престаје бити проклитика, а нека нпр. именска реч или глагол притом могу бити неакцентовани, што их не чини клитикама. Поред тога, у говору се често може десити да се речи које иначе имају свој акценат због темпа и/или немарности изговоре неакцентовано. Дакле, кључна реч у дефиницији из прве реченице је свој - клитике су речи које не поседују, не могу имати сопствени акценат у језичком систему, за разлику од акиентогених речи (Пецо 1985: 84), тј. ортотоничних речи (Петровић - Гудурић 2010: 366). Неакцентована реч је термин са ширим опсегом: у одређеним контекстима проклитике могу бити акцентоване, а акцентогене/ортотоничне речи изгубити свој акценат; проклитике су чешће неакцентоване, а нпр. именице или глаголи чешће акцентовани, али ни једно ни друго не мора важити увек.

1.2. Проблем настаје код представљања њиховог инвентара, нарочито проклитика у аспектима који су традиционално занемарени у настави, а који се могу озбиљно косити с учениковим језичким осећањем. Све граматике наводе како у проклитике спадају предлози, везници и речца не, а у енклитике краћи/енклитички облици од јесам и хтети, краћи/енклитички облици личних заменица (укључујући ту и повратну себе, се) и речца ли (Кликовац 2011а: 48; Штасни - Добрић 2012: 138; Ломпар 2017г: 140; Срдић et al. 2017в: 146; Кликовац 2018: 61).

1.2.1. Проклитике. Набрајање или табеларни прикази проклитика најпре морају бити прецизнији ако се не жели створити генерализација да су сви предлози и везници проклитике и да је речца не увек проклитика, што се најчешће и постиже, тражећи од ученика да се класификација научи напамет. То није тачно. Неки предлози се тешко могу изговорити без свог акцента (нпр. найсуnрот вра́тима, пре̂ нѐдељее, ̀̀пркос/упр̀кос пробле́мима), а многи могу факултативно имати свој акценат, зависно од говорника (нпр. испод про́зора и йспод про́зора). ${ }^{1}$ Речца не најчешће јесте проклитика, али кад стоји самостално, има свој краткосилазни акценат (нпр. Нё, нѐмо̄j ми при́ћu/npиिћu).

Поред тога, у проклитике могу спадати и друге речце, нпр. 3ap je то мӧzйће/ могýћe? (но, никако све, како се погрешно наводи у: Журић - Ангеловски 2012б: 134, уп. међуेтимм, мӧжда/мо̀жда), али и заменице и прилози када су у функцији

\footnotetext{
${ }^{1}$ О случајевима у којима исто важи и за неке везнике је већ писано (Стевановић 1991а: 84-89).
} 
субординатора, нпр. Гӧдине које су појјели ска̄ка̄вци/ска̀ка̄вци; оेна̄j чије се йме нѐ смё изговорити; Йдё/Йде где га по̀шаљу; „И зва́ла се како се зва́ла // Рѐциио Вёра Павладоेљска̄ // И изгле́дала како је изгле́дала" и др.

Стога би инвентар најбоље било формулисати слично ономе како је то већ учинио М. Стевановић: „проклитике су обично предлози и везници [може се овде додати: и речца не], мада то теоријски може бити и друга која реч без [сопственог] акцента која се акценатски наслања на реч иза себе [подвлачење и допуна Н. Р.]" (Стевановић 1991б: 164), а при одабиру примера у обради и вежбањима треба строго водити рачуна о томе да се не поткраде грешка у вези с приказаним проблематичним случајевима. ${ }^{3}$

1.2.2. Енклитике. Статус енклитичких облика глагола бити за грађење потенцијала није стабилан у поређењу с јесам и хтети, али их углавном има, мада често посредно, подразумеваних у склопу синтагме „помоћни глаголи” (Кликовац 2011а: 48; Журић - Ангеловски 2012б: 134; Маринковић 2015: 37; Ломпар 2017г: 132; Срдић ет ал. 2017в: 147; уп. нпр. у: Штасни - Добрић 2012: 138, где се наводе енклитички облици помоћних глагола, али у загради с примерима изостаје само илустрација ове групе).

Код енклитика потпуно је занемарена повратна речца се. На једном месту срећемо истакнуту нејасну „морфему се” (Штасни - Добрић 2012: 138), што је непрецизно јер се може односити и на заменицу. ${ }^{4}$

Енклитички заменички облик акузатива ґ налазимо само на једном месту (Журић - Ангеловски 2015: 135).

1.3. За ученике је корисно да знају дистрибуцију наглашених и ненаглашених облика заменица, с тим што бисмо формулацију где наглашене „употребљавамо” (или, мало касније у тексту, „најчешће употребљавамо”) (Ломпар 2017а: 40) ради прецизности изменили у где се оне „морају употребити” - на почетку реченице и иза паузе у говору, односно зареза у писању. Исти статус као претходним контекстима не бисмо дали позицији иза предлога (ibid.), jep се енклитички облици заменица, иако у ретким случајевима, ипак могу срести иза предлога, у примерима као што су прёда̄ ce, на́ ме, за́ те и сл. (Стевановић 1991а: 151-152), које ученици могу прочитати и у школској лектири. Тврдњу да се ненаглашени облици личних заменица ме и те пишу уз енклитички облик од јесам, нпр. Неко ме је тражио (Срдић et al. 2017б: 49) треба прецизирати - вероватно се хтело рећи да се у тим позицијама енклитички облици заменица морају писати испред глаголске енклитике $j$, што важи и за све друге енклитичке облике заменица, а не само за ме и те (Поповић 2004: 283-364).

1.4. Наилазимо на информацију да се ненаглашени облици заменица чешће употребљавају (Николић - Николић 2011а: 93).

\footnotetext{
${ }^{2}$ Прилог како овде изговорен као проклитика може се лепо чути и у рецитовању М. Бећковића: https://www.youtube.com/watch?v=HnHJMwm3PUQ

${ }^{3}$ Више речи о томе планирамо изнети у следећем раду, који би се бавио примерима у уџбеницима.

${ }^{4}$ Ово се даље може одразити и на морфолошки план, познавање врста речи - ученик може поистовећивати заменицу се и речцу се.
} 
1.5. Преношење акцента на проклитику је у свим граматикама објашњено и поткрепљено примерима у складу с литературом о овом питању (Стевановић 1991а: 31-32, 126-128, 133-134, 136, 140, 144; 1991б: 164-165, 223-224, 231, 240-241, 247, 358-376; Јокановић-Михајлов 2012: 27-31), уз за нас оправдано истицање одричних облика презента глагола као важне категорије, као и чињенице да су и облици с преношењем акцента исправни (Кликовац 2011a: 24; Штасни - Добрић 2012: 141; Ломпар 2017г: 132-133, 140; Срдић et al. 2017в: 148; Кликовац 2018: 60), изузимајући непрецизност у оцени да се акценат понекад преноси, а понекад не (Маринковић 2015: 37). Приметан је пак скоро потпуни недостатак примера с метатонијском дужином насталом преношењем дугосилазног типа раิдйм : нѐ ра̄дйм, што је у вези и с начелним одсуством метатоније у граматикама; једини пример ове врсте који смо пронашли је спаิва̄м : нѐ спа̄ва̄м (Кликовац 2018: 61).

\section{2. Фонетска природа акцената и постакценатске дужине}

2.0. Тачност и прецизност фонетског описа акценатских елемената функционише у усвајању фонолошких опозиција у акцентуацији на два нивоа.

Ђак који у свом говору има фонолошку опозицију може га користити као ослонац и контролора описа који му се у граматици пружа да би ту опозицију перципирао и схватио.

За говорника који нема неку опозицију у свом систему, рецимо, квалитет акцента у динамичкој акцентуацији дела призренско-тимочког дијалекта, усвајање фонолошке разлике не може ићи путем идентификације са сопственим говором, већ се ђак искључиво, уз неопходну дозу језичког осећања, мора научити да продукује одређене акустичке карактеристике говорног сигнала подражавањем датог фонетског описа. У случају погрешног описа, биће научен криви акустички сигнал.

\section{1. Акценат и акцентованост}

2.1.1. За већину граматика појмови акцента и акиентованости подразумевају (посебно/нарочито) истицање слога у речи, те се за такве слогове каже да су наглашени или акиентовани. Каткад се за такво истицање, вероватно ради прецизирања, користи атрибут „гласовно” (Николић - Николић 2011б: 81).

2.1.2. Суптилне разлике се запажају у навођењу акустичких компонената говорног сигнала којима се врши то истицање: за једне је то примарно јачина („гласовни удар” у: Драгићевић 2011: 93; ,јачина гласа” у: Николић - Николић 2011б: 81; „снажније” у: Журић - Ангеловски 2012а: 45; ,,јаче” у: Журић - Ангеловски 2015: 18; „појачани изговор једног слога у речи” у: Ломпар 2017б: 119; Ломпар 2017г: 129; Кликовац 2018: 59), за друге - јачина и висина (Журић - Ангеловски 2012б: 132; Вуловић 2016: 174; Срдић 2017a: 138; Срдић et al. 2017a: 145) или јачина и дужина/краткоћа слога (Маринковић 2014: 81; Срдић 2017a: 
138) а може се срести и комбинација дужине (трајања), јачине (снаге) и висине (Журић - Ангеловски 2012а: 46; Журић - Ангеловски 2012б: 132).

Пошто различита фонетска природа акцената у појединим четвороакценатским говорима (в. т. 2.3.3-2.3.4) диктира и различит фонолошки статус свих поменутих акустичких параметара говорног сигнала, овде би било најбоље одлучити се или за заустављање на томе да је реч о посебном/нарочитом (гласовном) истицању слога, или да, ако желимо прецизирати, то учинимо спомињући сва три акценатска елемента: јачину, дужину/краткоћу и боље кретање тона / тонско кретање него „висину”. Иако се кретање тона / тонско кретање односи само на висину, тј. фреквенцију у фонетском смислу, термини нису синонимни (Јокановић-Михајлов 2012: 100-104). Српски језик спада у посебну групу језика с тзв. тонском акцентуацијом, где је фонолошки релевантно управо кретање тона / тонско кретање у оквиру слогова, док је висина општи назив једне од акустичких компонената говорног сигнала, која је градивни чинилац и гласова, јединицаิ инхерентног нивоа, али и која се у самој акцентуацији може фонолошки употребити на сасвим други начин, који није присутан у српском језику и оне језике у акценатском смислу њему сродне. Стога сматрамо да би употреба термина кретање тона / тонско кретање једноставно погодила суштину и потпуно елиминисала јављање евентуалних нејасноћа и заблуда.

У почетном објашњавању самог феномена акцентованости једног слога у речи, добродошла је (иначе, у граматикама ретка) аналогија према наглашавању једне речи у реченици (Срдић 2017а: 138), да би се створио паралелизам у принципу реализовања сродних фонетских појава (не у њиховој функционалности, која је нешто другачија).

2.1.3. Но, иако се у самом дефинисању акцента он без изузетка исправно везује за слог, проблем се јавља у даљој недоследности граматика кроз навођење „акцентованих/наглашених самогласника” (Николић - Николић 2011a: 143; Кликовац 2015: 167-168; Ломпар 2017г: 130; Срдић et al. 2017в: 142), „висине гласа" (Журић - Ангеловски 2012а: 46) и сл. Овакве формулације треба избећи, јер ученике могу навести на погрешну помисао да се акценат, уместо на слогу, најмањој јединици прозодијске организације говора (Јокановић-Михајлов 2012: $123)$, заправо налази на фонеми, тј. вокалу или слоготворном сонанту, што је ионако потпомогнуто чињеницом да се ознаке заиста бележе изнад појединачних графема. Ако се у тим ситуацијама већ жели обратити пажња баш на самогласник или слоготворни сонант, што је разумљиво кад се узме у обзир и тежина одређивања прецизне границе између појединих слогова, то се лако може учинити коришћењем синтагми носилаи акцентованог слога / слоготворни глас.

\section{2. Опозиција по квантитету акцентованог слога}

2.2.1. Мишљења смо да у основношколском образовању није потребно користити термин квантитет акцента и сасвим нам је оправдано и довољно што се за акценатску опозицију по квантитету наводи да слог може бити дуг или 
кратак (Драгићевић 2011: 93; Николић - Николић 2011а: 88, 143; Журић - Ангеловски 2015: 18; Кликовац 2015: 167; Вуловић 2016: 174; Вуловић - Рудњанин 2016: 126; Срдић 2017a: 138). Евентуална препорука би била да се за квантитет избегне употреба речи „дужина” (Журић - Ангеловски 2015: 19; Вуловић 2016: 174; Ломпар 2017г: 129), само да би се спречила могућа интерференција не толико с термином „неакцентована дужина” колико с дужином на инхерентном нивоу, тј. бројем гласова у речи. Замена фонетским термином трајање (Журић - Ангеловски 2015: 18) није добро решење јер и два, нпр. дуга, акцента могу различито трајати у фонетском смислу; трајање је фонетски термин (ЈокановићМихајлов 2012: 110-117).

Дешава се пак да се „квантитет” одједном појави, иако је претходно као термин доследно коришћена само „дужина” (Николић 2011: 66-67), што може збунити ученике и за чим нема потребе на овом узрасту.

2.2.2. Опозицију по квантитету акцентованог слога граматике начелно не обрађују детаљно теоријски, и заустављају се на упоређивању примера с дугим и кратким акцентованим слогом. Врло ретко налазимо да кратки акценти трају двапут краће од дугих, што је апроксимација пригодна узрасту (Милановић 2009: 147). Иако, по нашем искуству, одређивање квантитета акцента није значајан проблем за ученике који опозицију имају у свом систему, могао би се о њој чешће у текст укључити и неки савет, као што је тај да ученик проба да одреди да ли је слог дуг или кратак тако што знатно продужи, па скрати акценат у некој речи (Журић - Ангеловски 2012а: 45). Довољно би, можда, било рећи да се кратки акценти могу изговорити и максимално скраћено, а да се фонолошки ништа не промени, док исто не би важило за дуге акценте; продужавање кратких акцената је тежи поступак, јер би се могао јавити проблем у вези с тонским кретањем.

\section{3. Опозиција по квалитету акцентованог слога}

2.3.1. Претходно речено за помињање термина квантитет у том виду важи и за термин квалитет акцента, с тим да је овај акценатски елемент, будући мало компликованији, потребно опрезније описати, што граматике и чине. Непрецизно је да је реч о „дизању и спуштању гласа” (Николић - Николић 2011а: 144; Вуловић - Рудњанин 2016: 127), јер се то може повезати и с јачином. Најбоље - да се тон спушта и подиже (Вуловић - Рудњанин 2016: 126; Срдић et al. 2017a: $148,150)$. За опозицију по квалитету акцента препоручљиво је избегавати, иако је устаљен, термин силазна и узлазна интонащија (Николић 2011: 63-64; Журић - Ангеловски 2012а: 46; Штасни - Добрић 2012: 139; Вуловић - Рудњанин 2016: 126; Ломпар 2017б: 120; Ломпар 2017г: 129; Срдић et al. 2017a: 148; Срдић et al. 2017б: 190; Срдић et al. 2017в: 141, 142) из оправданог страха да се може помешати с истоименим термином за друге појаве на супрасегментном нивоу. Сасвим је довољно: силазно и узлазно кретање тона / тонско кретање. 
У уџбеницима се, као и код квантитета (в. т. 2.2.1), може изненада наићи и на потенцијално збуњујућ „квалитет” (Николић 2011: 66-67; Срдић et al. 2017в: $142)$, за чим, опет, нема потребе на овом нивоу.

2.3.2. У граматици за 6. разред, као увод у обраду тонске разлике између дугих акцената користи се аналогија с викањем или шапатом у обраћању саговорнику у зависности од тога какав ефекат желимо постићи, са закључком да увек треба прилагодити тон гласа ситуацији у којој се налазимо (Срдић et al. 2017a: 148). Иако сама по себи занимљива, аналогија на овом месту може бити проблематична ако се изгуби из вида да се разлика између викања и шапата примарно односи на акустичку компоненту јачине, или ако се квалитет акцената случајно поистовети с тонском, интензитетском и/или тембралном компонентом интонације (Јокановић-Михајлов 2013: 205-212, 219-220).

2.3.3. Опозиција по квалитету ДУГИХ акцената. Опозицију по квалитету дугог акцентованог слога све граматике објашњавају на следећи начин: на акцентованом слогу под дугоузлазним тон све време расте, а под дугосилазним тон прво расте, па опада; мада се свакако хтело рећи исто, можда је незгодна формулација да се подиже „глас”, јер се то може схватити као ствар јачине, а не тона (Николић 2011: 64; Журић - Ангеловски 2012а: 46; Кликовац 2015: 167; Маринковић 2015: 70; Вуловић - Рудњанин 2016: 126-127; Ломпар 2017б: 120; Срдић et al. 2017a: 148-149; Ломпар 2017г: 130); на једном месту налазимо и да снага пред крај слога под дугоузлазним мало пада (Маринковић 2015: 70).

Ако се гласовним средствима код дугосилазног постиже да је у првој фази реализације највиши тон, за чим следи дуготрајнији пад тона у другој фази, о чему нема дилеме (Пецо 1985: 55-70; Ивић - Лехисте 2002: 153-159; Јокановић-Михајлов 2013: 43-102; Средојевић 2017: 2013), фонетски је потпуно тачно да би се такво кретање могло осликати као лук (Милетић 1960: 88), на шта се асоцира и његовом ознаком, што често, као што смо горе видели, прати и опис тонског кретања овог акцента као лучног. Међутим, перцептивно би ствар могла бити нешто другачија. Оно што ми доминантно чујемо, на шта је указао и Б. Милетић (ibid.), и што је за нас фонолошки пресудно код овог акцента, заправо јесте друга фаза - дуготрајни тонски пад. Зато сматрамо да је у настави инструменталније, а и акустички и аудитивно тачно, да описи овог акцента полазе од чињенице да се на почетку слога постиже највиши тон, за чим следи пад тона.

Узлазно кретање тона у акцентованом слогу под дугоузлазним акцентом свакако је регистровано у шумадијском говору, говорима западне Србије и ијекавским говорима херцеговачког типа (Јокановић-Михајлов 2013: 60-70), што, поред самих тих говорника - означићемо их као I тип - може бити и препоручени узор за ђаке из система који нема опозицију по квалитету. Међутим, закључак да у српским говорима постоји неколико типова дугоузлазног акцента, у оном делу где је тонско кретање неких његових варијаната - београдског говора означићемо га као II тип - и војвођанских говора - што ће за нас бити III тип - у оквиру акцентованог слога описано као претежно равно (Белић 1926-1927: 230; Пецо 1985: 55-70; Ивић - Лехисте 2002: 153-159; Јокановић-Михајлов 2013: 
70-94; Средојевић 2017: 213-214), има последице по тачност горенаведеног описа и може отежати усвајање акцента, те тиме и опозиције, код говорника поменутих типова; Д. Средојевић чак ни код дугоузлазног акцента у војвођанским говорима тонско кретање у оквиру акцентованог слога не узима као фонолошки релевантно, већ заступа тезу о двосложности овог акцента (за дискусију о једносложности и двосложности наших узлазних акцената исп. Пецо 1985: 55-70; Ивић - Лехисте 2002: 153-159; Петровић - Гудурић 2010: 367-369; ЈокановићМихајлов 2013: 43-102; Средојевић 2017: 193-198), тј. фонолошким сигналом сматра однос акцентованог и постакценатског слога - низак тон у акцентованом и виши у постакценатском (2017: 221), што је продужетак резултата и закључака П. Ивића и И. Лехисте (2002: 153-159).

Ако би се морало поћи за заједничком карактеристиком и уопштеним описом, у складу са претходно реченим, сматрамо да би за ученике онда најкорисније опозицију по квалитету између дугоузлазног и дугосилазног акцента исказати на следећи начин: разлика у тонском кретању у оквиру акцентованог слога постоји - код дугосилазног је присутан пад тона, за разлику од дугоузлазног, где он изостаје.

2.3.4. Опозиција по квалитету КРАТКИХ акцената. Уз (сасвим тачно и оправдано) упозорење да је кратке акценте најтеже разликовати (Милановић 2009: 147, Срдић et al. 2017б: 190), не помаже много упутство да је потребно да се сконцентришеш и покушаш да чујеш себе (Срдић et al. 2017б: 190). Како граматике покушавају ученицима приближити за усвајање наших акцената најтеже - опозицију по квалитету код кратких акцената?

Највећи проблем за ученике је што се граматике при овоме скоро увек фокусирају на акцентовани слог. Тако најчешће читамо да се код краткосилазног тон (негде се каже и „глас”, што је можда непрецизно из разлога у т. 2.3.1, 2.3.3) за кратко време прво подиже, па спушта, док се код краткоузлазног тон накратко подиже, али без пада у оквиру акцентованог слога (Ломпар 2017в: 140; Ломпар 2017г: 130; Срдић et al. 2017б: 190; Срдић et al. 2017в: 141). Маринковић за краткосилазни наводи само пад, а код узлазног најпре кратак раст, па пад при крају акцентованог слога (2013: 36). За краткосилазни се још може наћи да има јачи удар (Срдић et al. 2017б: 190), да траје веома кратко, као удар на слог (Ломпар 2017в: 140; Ломпар 2017г: 130), да је тонски пад нагли (Срдић et al. 2017б: 190) и да исто важи за јачину (Милановић 2009: 147; Николић 2011: 64; Маринковић 2013: 36), а за краткоузлазни и да се јачина уздиже (Николић 2011: 64; Маринковић 2013: 36).

Прво, иако шумадијски говор, говори западне Србије и ијекавски говори херцеговачког типа (I тип), што је за неке од њих наслутио А. Белић (1926: 230), показују изразито тонско кретање у оквиру слогова под кратким акцентима (Joкановић-Михајлов 2013: 60-70), какво, поред говорника с ових подручја, и за ђаке из система без опозиције по квалитету може бити употребљено као препоручени узор, регистровано је да је у београдском говору (II тип) акцентовани слог код краткоузлазним (као што је то био случај и с дугоузлазним) заправо 
раван (Јокановић-Михајлов 2013: 70-94; уп. Белић 1926: 230), а у војвођанским говорима (III тип) тонско кретање у оквиру акцентованог слога сматра се фонолошки редундантним (Ивић - Лехисте 2002: 153-159; Јокановић-Михајлов 2013: 94-96; Средојевић 2017: 213-214).

Но, чак и ако ученик припада првој поменутој групи говора, те има изразито узлазно кретање у оквиру акцентованог слога, кратки акценти сувише кратко трају да би ученици могли чути ову суптилну фонетску разлику. То посебно важи за тонско кретање, али нам ни трајање ни јачина неће бити савезници, јер и краткоузлазни акценат можемо у највећој мери скратити и појачати, а да се његов узлазни тон не промени.

На правом трагу налазимо ауторе када истичу да се слог иза краткосилазног, услед наглог силазног тонског кретања, изговара у врло ниском тону (Николић 2011: 64), ниже од наглашеног (Журић - Ангеловски 2012б: 133; Штасни - Добрић 2012: 140). Суштина је, заправо, у усмеравању пажње ученика на први по-стакценатски слог. Притом не мислимо на однос акцентованог и постакценатског слога. Он у поменутим говорима није исти ни што се тиче фонетске природе, ни што се тиче њене фонолошке релевантности. У онима где је тонско кретање у оквиру акцентованог слога изразито, регистровано је да први постакценатски слог иза краткоузлазног акцента од самог свог почетка може бити нижи од акцентованог (Јокановић-Михајлов 2013: 85), али је код других поменутих (не у свим четвороакценатским говорима, како се сугерише у: Журић - Ангеловски 2012б: 133; Штасни - Добрић 2012: 140) слог иза краткоузлазног акцента по тону њему једнак или виши од њега, на шта је указивао и А. Белић (1926: 230); дакле, док је у првим фонолошки релевантно кретање тона у оквиру акцентованог слога, у овим другим релевантна је заправо висина постакценатског слога у односу на акцентовани (Ивић - Лехисте 2002: 153-159; Јокановић-Михајлов 2013: 94-96; Средојевић 2017: 221).

Но, код кратких акцената постоји једна згодна заједничка карактеристика свих ових говора, на којој можемо градити методички приступ. Треба, у ствари, узети две речи истог броја слогова, по могућству што сличније по фонемском саставу, а различитог кратког акцента у истој позицији, и међусобно упоређивати следеће: први постакценатски слог иза слога с краткоузлазним акцентом с таквим слогом иза слога с краткосилазним акцентом, јер, о којем год говору од поменутих да је реч, перцептивно је слог иза краткоузлазног акцента увек на већој висини него онај иза краткосилазног. И то је кључно за истицање ученичком уху при почетном усвајању. Нпр. узмимо речи у̀nала (р. гл. придев гл. у̀nасти у ж. р. јд.) и у́пала (ном. јд. именице) и упоређујемо слогове ПА у обе речи: слог ПА у првој речи на већој је висини него слог ПА у другој.

У складу с претходно реченим, илустрације краткоузлазног дате у неким граматикама где је графички издигнут само део акцентованог слога (Ломпар 2017в: 140, Ломпар 2017г: 130): 


$$
\text { сто } о \text { лица }
$$

делимично одговарају само за говоре с фонолошки релевантним кретањем тона у оквиру акцентованог слога, с тим да је постакценатски ниво ипак нешто виши него што илустрација сугерише; с друге стране, из илустрација где је језгро акцентованог слога под краткосилазним графички најпре издигнуто, па спуштено у односу на постакценатски (Ломпар 2017в: 140, Ломпар 2017г: 130):

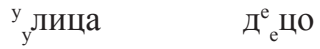

може се десити да ученици закључе да је крај акцентованог слога под краткосилазним тонски нижи од постакценатског, што типично није случај, осим под утицајем интонације (Ивић - Лехисте 1996: 205-266).

Неодговарајуће је и графички изједначити све постакценатске слогове (Штасни - Добрић 2012: 140):

$$
\text { вйдети: вети сѐдети: се }
$$

\begin{tabular}{|c|c|c|c|}
\hline & \multicolumn{3}{|c|}{ ДУГИ АКЦЕНТИ } \\
\hline & дУГОУ & АЗНИ & ДУГОСИЛАЗНИ \\
\hline $\begin{array}{l}\text { I ТИП } \\
\text { (нпр. источнохерцего- } \\
\text { вачки) }\end{array}$ & $\begin{array}{l}\text { P } \\
\text { Py } \\
\text { Py }\end{array}$ & KA & \multirow{3}{*}{$\begin{array}{l}\text { Py } \\
\text { Py } \\
\qquad \begin{array}{l}\text { Py } \\
\text { KO }\end{array}\end{array}$} \\
\hline $\begin{array}{l}\text { II ТИП } \\
\text { (нпр. београдски) }\end{array}$ & РУУУ & $\begin{array}{l}\text { KA } \\
(\mathrm{KA})\end{array}$ & \\
\hline $\begin{array}{l}\text { III ТИП } \\
\text { (нпр. новосадски) }\end{array}$ & рууу & KA & \\
\hline
\end{tabular}$$
\text { дети }
$$

јер се тиме сугерише да су они исти по тону, што никада није случај.

2.3.5. У табелама које следе наводимо, мора се рећи, опет приближну, слику фонетске природе наших узлазних и силазних акцената, према претходно изнетим досадашњим испитивањима:

Табела 1. Фонетска природа дугих акцената

Висина графема у оквиру поља одговара релативној висини тона. 
Табела 2. Фонетска природа кратких акцената

\begin{tabular}{|l|c|c|}
\hline \multirow{2}{*}{} & \multicolumn{2}{|c|}{ КРАТКИ АКЦЕНТИ } \\
\cline { 2 - 3 } & КРАТКОУЗЛАЗНИ & КРАТКОСИЛАЗНИ \\
\hline $\begin{array}{l}\text { I ТИП } \\
\text { (нпр. источнохерцего- } \\
\text { вачки) }\end{array}$ & СТО ЛИ ЦТО \\
\hline $\begin{array}{l}\text { II ТИП } \\
\text { (нпр. београдски) }\end{array}$ & СТО ЛИ ЦА & \multicolumn{2}{|c|}{ У } \\
\hline $\begin{array}{l}\text { ІІІ ТИП } \\
\text { (нпр. новосадски) }\end{array}$ & СТО ЛИ ЦА \\
\hline
\end{tabular}

Висина графема у оквиру поља одговара релативној висини тона. Удвојени слогови овде илуструју тонско кретање у оквиру акцентованог слога, а не дуге слогове.

\section{4. Опозиција по квантитету постакценатског слога}

За неакцентоване слогове се, што је у складу с литературом (Јокановић-Михајлов 2013: 121), констатује да могу бити дуги и кратки (Срдић et al. 2017в: 145; Кликовац 2018: 60) и да се у стандардном језику неакцентована дужина може јавити само после акцентованих слогова (Маринковић 2013: 38; Ломпар 2017г: 131; Срдић et al. 2017в: 145; Кликовац 2018: 60).

У неким граматикама налазимо податак да вокал у дугом постакценатском слогу траје двапут дуже од оног у кратком, и да је тон на дугом постакценатском слогу раван (Маринковић 2013: 38; Ломпар 2017г: 131). Апроксимација за квантитет је разумљива с обзиром на узраст, једино што бисмо додали могућност да тонско кретање буде и силазно (Јокановић-Михајлов 2013: 121-125).

Похвално је да се при обради неакцентоване дужине упућује на везу са генитивним знаком, сродном наставном јединицом из Правописа (Ломпар 2017г: 131).

\section{3. Закључак}

3.0. У раду смо анализирали поступак обраде једног дела градива из акцентологије у граматикама од 5. до 8. разреда основне школе, и то тачност и прецизност у дефинисању и опису фонолошких елемената у акцентуацији српског језика. 
3.1. Услед другачијег фонолошког статуса акустичких карактеристика говорног сигнала у зависности од фонетске природе акцената у појединим четвороакценатским говорима, јавља се проблем у проналажењу опште дефиниције саме акцентованости која ће све њих обухватити. Предложено решење је да се граматике или не упуштају у навођење акустичких параметара и представе акцентованост само као посебно истицање слога у речи, или, што је за нас боље, јер је информативније, а није оповргљиво, да их наведу све као могућност, уз ограду да их поједини четвороакценатски говори употребљавају у различитој мери (в. т. 2.1.2).

3.2. Знатне недостатке и непрецизности показује сфера проклитика и енклитика, у навођењу јединица које улазе у њихов инвентар (в. т. 1.2).

3.3. Разноврсна и сложена слика фонетске природе акцената у четвороакценатским говорима отежава њихово појединачно описивање и успостављање мерила за њихово међусобно опонирање која из тих описа следе (в. т. 2.3). Највеће неуједначености присутне су у домену кратких акцената, али се може посебно истаћи да граматике начелно пропуштају да описе свих акцената ускладе са ситуацијом изван источнохерцеговачких и „севернијих млађих новоштокавских говора" (назив по Б. Николићу, уп. 1968, 1969, 1970). Ово наводимо као, пре свега, методички проблем, из разлога што се тиме, поред јасних импликација за отежано усвајање акцента веродостојног звучања за говорнике из система без опозиције, неприказивањем варијантности може интерферирати са језичким осећањем ђака чије су варијанте искључене и тиме онемогућити да препознају свој акценат у пруженим описима, а на том изостанку идентификације се даље теже могу градити вежбе у препознавању и упоређивању акцената на основу сопственог говора.

\section{КОРПУС}

Вуловић 2016: Наташа Вуловић, Српски језик и језичка култура за пети разред основне школе, Београд: Завод за уџбенике - Бирограф.

Вуловић - Рудњанин 2016: Наташа Вуловић, Сандра Рудњанин, Српски језик и језичка култура за 6. разред основне школе, Београд: Завод за уџбенике - Scanner Studio.

Драгићевић ${ }^{32011: ~ Р а ј н а ~ Д р а г и ћ е в и ћ, ~ С р п с к и ~ ј е з и к ~ и ~ ј е з и ч к а ~ к у л т у р а ~ з а ~} 5$. разред основне школе, Београд: Завод за уџбенике - Нови Сад: Стојков. [2007]

Журић - Ангеловски 2015: Јелена Журић, Јелена Ангеловски, Жубор језика: српски језик и језичка култура са вежбанима за пети разред основне школе, Београд: Едука - Цицеро. [2013]

Журић - Ангеловски 2012а: Јелена Журић, Јелена Ангеловски, Говор и језик: српски језик и језичка култура са вежбањима за шести разред основне школе, Београд: Едука, Суботица: Ротографика. [2011] 
Журић - Ангеловски 2012б: Јелена Журић, Јелена Ангеловски, Српски језик и језичка култура: уибеник са вежбањима за седми разред основне школе, Београд: Едука, Суботица: Ротографика. [2011]

Кликовац 22011: Душка Кликовац, Српски језик и језичка култура за 8. paзред основне школе, Београд: Завод за уџбенике - Бирограф. [2010]

Кликовац 22015: Душка Кликовац, Српски језик за седми разред основне школе, Београд - Креативни центар, Крагујевац - Графостил. [2009]

Кликовац 42018: Душка Кликовац, Граматика српског језика за основну школу, Београд: Креативни центар - Крагујевац: Графостил. [2010]

Ломпар 102017а: Весна Ломпар, Граматика 5: српски језик за пети разред основне школе, Београд: Klett - Службени гласник, 2017. [2007]

Ломпар 102017б: Весна Ломпар, Граматика 6: српски језик за шести разред основне школе, Београд: Klett - Службени гласник, 2017. [2008]

Ломпар 72017в: Весна Ломпар, Граматика 7: српски језик за седми разред основне школе, Београд: Klett - Службени гласник, 2017. [2010]

Ломпар 72017г: Весна Ломпар, Граматика 8: српски језик за осми разред основне школе, Београд: Klett - Службени гласник, 2017. [2010]

Маринковић 2014: Симеон Маринковић, Српски језик за 5. разред основне школе, Београд: Креативни центар - Публикум.

Маринковић 2015: Симеон Маринковић, Српски језик за 6. разред основне школе, Београд: Креативни центар - Публикум.

Маринковић 2013: Симеон Маринковић, Српски језик за 8. разред основне школе, Београд: Креативни центар - Публикум.

Милановић 2009: Александар Милановић, Српски језик и језичка култура за 7. разред основне школе, Београд: Завод за уџбенике - Публикум.

Николић - Николић ${ }^{32011 a: ~ М и л и ј а ~ Н и к о л и ћ, ~ М и р ј а н а ~ Н и к о л и ћ, ~ С р п с к и ~}$ језик и језичка култура: за 5. разред основне школе, Београд: Завод за уџбенике - Ниш: Галеб. [2007]

Николић - Николић 42011б: Милија Николић, Мирјана Николић, Српски језик и језичка култура: за б. разред основне школе, Београд: Завод за уџбенике - Ниш: Галеб. [2008]

Николић ${ }^{32011 в: ~ М и л и ј а ~ Н и к о л и ћ, ~ С р п с к и ~ ј е з и к ~ и ~ ј е з и ч к а ~ к у л т у р а: ~ з а ~} 7$. разред основне школе, Београд: Завод за уџбенике - Публикум. [2009]

Срдић 72017: Јелена Срдић, Дар речи: граматика за пети разред основне школе, Београд: Нови Логос, 2017. [2011]

Срдић et al. ${ }^{72017 a: ~ Ј е л е н а ~ С р д и ћ, ~ С л а ђ а н а ~ С а в о в и ћ, ~ Д р а г а н а ~ Ђ е ћ е з ~ И љ у-~}$ кић, Дар речи: граматика за шести разред основне школе, Београд: Нови Логос, 2017. [2011]

Срдић et al. ' 2017б: Јелена Срдић, Слађана Савовић, Драгана Ђећез Иљукић, Дар речи: граматика за седми разред основне школе, Београд: Нови Логос, 2017. [2012] 
Срдић et al. ${ }^{\mathbf{2 2 0 1 7}}$ : Јелена Срдић, Слађана Савовић, Драгана Ђећез Иљукић, Светлана Вулић Дар речи: граматика за осми разред основне школе, Београд: Нови Логос, 2017. [2010]

Штасни - Добрић 22012: Гордана Штасни, Наташа Добрић, Српски језик и језичка култура: уцбеник са вежбањима за осми разред основне школе, Београд: Едука, Суботица: Ротографика. [2011]

\section{ЦИТИРАНА ЛИТЕРАТУРА}

Белић 1926: Александар Белић, Др. Бранко Милетић, O srbochrvatských intonacích v nářeči štokavskem, Београд: Јужнословенски филолог, VI, 225-232.

Ивић - Лехисте 1996: Павле Ивић, Илсе Лехисте, Прозодија речи и речениие у српскохрватском језику (Целокупна дела Павла Ивића, том VII/1), Сремски Карловци - Нови Сад: Издавачка књижарница Зорана Стојановића.

Ивић - Лехисте 2002: Павле Ивић, Илсе Лехисте, О српскохрватским акичентима (Целокупна дела Павла Ивића, том VII/1), Сремски Карловци - Нови Сад: Издавачка књижарница Зорана Стојановића.

Јокановић-Михајлов 2012: Јелица Јокановић-Михајлов, Прозодија и говорна култура, Београд: Друштво за српски језик и књижевност Србије.

Јокановић-Михајлов ${ }^{22013: ~ Ј е л и ц а ~ Ј о к а н о в и ћ-М и х а ј л о в, ~ А к ц е н а т ~ и ~ и н-~}$ тонација говора на радију и телевизији, Београд: Друштво за српски језик и књижевност Србије. [2007]

Милетић ${ }^{2}$ 1960: Бранко Милетић, Основи фонетике српског језика, Београд: Научна књига. [1952]

Николић 1968: Берислав М. Николић, Ка основама акцентуације севернијих млађих новоштокавских говора, Београд: Наш језик, XVII/1-2, 59-82.

Николић 1969: Берислав М. Николић, Основне дијалекатске акценатске појаве у млађим новоштокавским говорима, Београд: Јужнословенски филолог, XXVIII/1-2, стр. 189-208.

Николић 1970: Берислав М. Николић, Основи млађе новоштокавске акценmуације, Београд: Институт за српскохрватски језик.

Петровић - Гудурић 2010: Драгољуб Петровић, Снежана Гудурић, Фонологија српскога језика, Београд: Институт за српски језик САНУ - Нови Сад: Матица српска.

Пецо ${ }^{3}$ 1985: Asim Peco, Osnovi akcentologije srpskohrvatskog jezika, Beograd: Naučna knjiga.

Поповић 22004: Љубомир Поповић, Ред речи у реченици, Београд: Друштво за српски језик и књижевност Србије. [1997] 
Средојевић 2017: Dejan Sredojević, Fonetsko-fonološki opis akcenata u standardnom srpskom jeziku: od specifičnog ka opštem, Novi Sad: Filozofski fakultet.

Стевановић 1991a: Михаило Стевановић, Кюига о акиенту књижевног језика, Београд: Завод за уџбенике и наставна средства.

Стевановић '1991б: Михаило Стевановић, Савремени српскохрватски језик (граматички системи и књижевнојезичка норма) I, Београд: Научна књига.

Nikola V. Radosavljević

ABOUT WORD ACCENT AND PHONETIC DESCRIPTION OF ACCENTS IN TEXTBOOKS OF THE SERBIAN LANGUAGE FROM 5TH TO 8TH GRADE OF ELEMENTARY SCHOOL

Summary

In this paper author presents one part of research results of accent material in textbooks of the Serbian language from 5th to 8th grade of elementary school. The author compares the definitions, explanations and examples of the words with and without accents (clitics) and evaluates the phonetic descriptions of word accent. The main objective of this study is to improve teaching methodologies.

Key words: Serbian language teaching methodology, phonetics and phonology of the Serbian language, accent, phonological oppositions, prosodic distinctive features, clitics. 